\title{
The effectiveness of use song lyrics as a medium in learning narrative writing skills
}

\author{
Eta Melfia ${ }^{1}$, Harris Effendi Thahar ${ }^{2}$ \\ \{etha.spears@gmail.com ${ }^{1}$, harrispadang@fbs.unp.ac.id $\left.{ }^{2}\right\}$ \\ ${ }^{1,2}$ Universitas Negeri Padang, Jl. Prof. Dr. Hamka Air Tawar Padang Sumatera Barat 25131, \\ Indonesia
}

\begin{abstract}
The lack of students' writing ability is one of the obstacles found in learning Indonesian language and literature. One of the causes of the lack of students' writing skills so far is the lack of variety of media used in the teaching and learning process. Therefore, a solution is needed to solve the problem. One solution that can be applied is to use the media of song lyrics in narrative writing learning. This type of research uses a quantitative approach. The research method applied is the experimental method. This type of experiment is quasi experiment or pseudo experiment . Article This aims to describe the effectiveness of the use of song lyric media in the learning of narrative writing skills of Class XI IPA students of SMAN 1 Sungai Aur in terms of the ability to express characters, conflicts, settings, plot, and the suitability of writing with the learning media.
\end{abstract}

Keywords: Song lyric media, narrative writing.

\section{Introduction}

Given the importance of writing skills, especially narrative writing, the right place is needed to practice and develop these skills. One such forum is an official educational institution better known as a school.

Narrative writing skills are important for students. Narrative writing skills have previously been studied by Sri Sutarni (2014), Suryo Daru Santoso (2013), Abikusno Cokro Suyono (2013). Sri Sutarni's research results (2014) showed that there was a significant influence on the use of cooperative group investigation (GI) methods and sentence structure mastery on narrative writing skills in Sragen High School. Suryo Daru Santoso research results (2013), showed that, the application of the cooperative learning model of two stay two stray techniques can improve the narrative writing skills of multicultural insights in class X Marketing 3 SMK Negeri 3 Surakarta. Abikusno Cokro Suyono (2013) examines the Effect of Cooperative Learning and Motivation on Narrative Writing Skills in Class X High School Students in Ponorogo Regency. The results of his research indicate that there is a significant influence and interaction between learning with a cooperative approach to exchanging pairs with those who learn through a cooperative approach to pairing and pairing, and motivation (high-low) on students' narrative writing skills.

According to (Tarigan; 2005, Mulyono: 2014, Saddono: 2015), writing skills will not come automatically, but must go through a lot of practice and practice. Like narrative writing, exercises are needed to produce good writing. Students are expected to be able to write a 
narrative using the appropriate diction when pouring ideas and ideas into their minds. A narrative writing can be used as a means to express themselves and feelings by utilizing the imagination of the writer.

Writer found some problems in learning the skill of writing narrative, as students have difficulty in expressing his ideas into written form intact, the lack of interest of the students to narrate an event through writing so that the flow of thoughts hopping, lack of ability sisw a developing paragraphs, and the inability of students to use the right diction selection.

From observations that have been made, the authors can draw conclusions that the occurrence of these problems is motivated by several factors. One of them is the lack of variety of media used by teachers in the learning process. Usually the teacher only asks students to write a narrative writing using the media contained in Indonesian language textbooks (picture media). For this reason, learning media are needed that have greater appeal to attract students' interest in learning to write narratives. Learning media in question are media that are closer to students' daily lives and are more in demand by students.

Based on the background of the problem, the problem identification is as follows. (1) Students have difficulty in pouring ideas into written form intact. (2) Lack of student interest in telling an event through writing so that the flow of thought jumps. (3) Lack of students' ability to develop paragraphs. (4) The inability of students to use proper diction selection.

\section{Method}

The This type of research uses a quantitative approach. Said to be quantitative because the data processed are required to use a lot of numbers, starting from data collection, interpretation of the data, as well as in the appearance of the results [12]. The number in this study is the score and value of the ability to write narrative grade XI student of SMAN 1 Sungai Aur. The research method applied is the experimental method. E experimentation is essentially an observation or observations of the causal link between the emergence of a result (the dependent variable) and the cause (independent variable) specific, through a deliberate effort by researchers. This type of experiment is quasi experiment or pseudo experiment [12].

\section{Result and discussion}

The markers Writing skills are one of the four aspects of language skills, namely listening, speaking, reading and writing. Writing is lowering or depicting graphic symbols that describe a language understood by someone, so that other people can read the symbols of the graph if they understand the language and graphic images [11]. Based on the above opinion, it can be concluded that writing is a process of moving language symbols into written forms that are readable, accurate, clear, and concise so that they can be understood by others. Writing is an activity of pouring ideas / thoughts into written form to publish to others. The general purpose of writing is as follows. 1) Give direction, which gives instructions to others in doing something. 2) Explain something, namely giving a description or explanation of something that must be known by others. 3) Tells the story, i.e. provides information about what is happening somewhere at a time. 4) Summarize (summarize), i.e. make a summary of the writing so that it becomes shorter. 5) Convincing, namely writing that tries to convince others to agree or agree with it [10].

To become a good writer, before starting to write, you must know the purpose of writing first. Writing without knowing the purpose will make someone confused in completing his writing. By knowing the purpose of writing, someone will be able to produce good and interesting writing. N Arasi is all text / work of fiction that is not shaped the dialogue, whose 
contents can be a historical story or series of events. In line with that, narration is a form of discourse whose main target is an act that is woven and assembled into an event that occurs in a single unit of time. Narration is a form of discourse that seeks to describe as clearly as possible to the reader an event that has occurred [5]. Furthermore, Kuntarto (2007: 224) revealed that narration is a form of writing that tries to describe as clearly as possible to the reader about events at a time to the reader. Atmazaki (2007: 90) also explains that narration is a story based on a sequence of events or events. In an incident, there is one or several characters and the person experiences one or a series of events. $\mathrm{N}$ Arasi is a form of speech or writing that aims to convey or recount the sequence of events or human experiences based on developments from time to time. Narrative is the delivery of a set of events or experiences about oneself, about others, or about oneself and others at a certain time or period of time [10].

Based on some of the opinions above, it can be concluded that the narrative is a writing that tells an event or human life events in one time unit. Thus, the notion of narrative includes actions or actions that have dialogue based on conflict in a time series. The events and events tell of the actions of the characters because of a conflict in a time series. The characteristic of narrative is to tell about human experience, both real events and imagination. The experience can be about the experience of yourself and others within a certain period of time. In addition, the characteristics of narration are the existence of conflict and social dialogue which makes it more lively and interesting. [3-11]

The narrative element is the same as the elements of a literary work consisting of intrinsic and extrinsic elements. Intrinsic elements are elements that build from within, such as: theme, plot, characterization, setting, mandate, point of view, and language style. Extrinsic element is an element that builds literary works from outside, such as: socio-economic, cultural, religious, and value-system factors adopted by the community.

The narrative structure can be seen from the components that make it up: actions, characterizations, settings, and points of view. But it can also be analyzed based on the plot (plot) of the narrative. Referring to the opinion of the experts above, the author focuses the narrative elements which will be discussed as follows. 1) The flow is the relationship between one event or group of other events. Next, divide the groove into two parts, namely conventional grooves and unconventional grooves. Conventional flow is if the event that is presented first always causes the emergence of events that occur afterwards, while the unconventional flow is the event that is told then becomes the cause of the event that was told before, or the event that is told first becomes the result of the event that is told afterwards. 2) Background, 1 Atar is any information about time, space, and the atmosphere of the lakuan in literature. . L Atar is a marker of identity problems began vaguely fictional scenes or characterizations are shown. The setting serves to clarify the atmosphere, place, and time of the event in effect. Furthermore, background elements can be divided into three main elements, namely place, time, and social. These three elements, although they offer different problems and can be discussed individually, are in fact interrelated and influence each other [6].

The background description can be physical, realistic, documentary and can also be a description of feelings. The setting is an environment that can function as a metonimia, metaphor, or expression of the characters [3].1) Viewpoint, perspective refers to how a story is told. The point of view in a narration questions how the relationship between someone who tells the narration with the actions that take place in the story. The point of view in a narrative is the way a writer sees all the actions in a narrative. S udut of view into two kinds, namely the first person (the style of "I") and a third person (the style of "him"). From both 
perspectives, a story is told. This first and third point of view can be used simultaneously in a work of fiction if it is felt to be more effective [8].

The perspective is a supporting element of fiction. During this time, the point of view is often also equated with the center of narration. If viewed from the point of communication between the author and the reader, then there is a difference between the point of view and the center of the narration. The point of view is a way for the reader to get fictional information, while the center of narration is a way for the author to convey information to fiction. 1) Characterization is the creation of the image of a character in the story. included in the characterizations are problems with naming, characterization, physical and psychological state, and character. Therefore, the author makes his characters appear alive and real. [6 ]

In the learning process strategies are needed to solve learning problems. One of them can be in the form of learning media. Many types of media that can be used. In its development, learning media follows technological developments. The last emerging technology is microprocessor technology which gave birth to computer usage and interactive activities. Based on this opinion, classify learning media into four groups as follows.

\subsection{Print technology results media}

Print technology is a way to produce or deliver material, such as books, and static visual material mainly through a mechanical or photographic printing process. Media included in this group are text, graphics, photographs, or photographic and reproductive representations. The two main components of this technology are verbal text material and visual material that is developed based on theories related to visual perception, reading, processing information, and learning theory.

\subsection{Media of audio visual technology results}

Audio-visual teaching is the production and use of material whose absorption through sight and hearing and is not entirely dependent on the understanding of words and similar symbols. Audio-visual teaching is characterized by the use of devices during the learning process, such as film projector machines, tape recorders, and wide visual projectors.

\subsection{Media based on computer based technology}

Computer-based technology is a way of producing or delivering material using sources that are micro-processor based. Characteristics of the use of this media is information / material delivered in digital form, not in printed or visual form.

\subsection{Combined media of print and computer technology}

Combined technology is a way to produce and deliver material that combines the use of several forms of media controlled by a computer [1]. Based media in terms of technological development into two groups as follows. (1) traditional media choices, consisting of projected silent visual media such as slides and filmstrips, non-projected visual media such as images, posters, photographs and graphics, audio media such as recordings and cassettes, multimedia presentations such as slides plus sound and multi-image, projected dynamic visuals such as film, television and video, print media such as textbooks and modules, games such as puzzles and simulations, and realia such as models and manipulatives. (2) the choice of the latest technology media, consisting of telecommunications-based media such as teleconferencing 
and distance lectures, media-based microprocessors such as computer games and compact (video) discs. [1].

\subsection{Media song lyrics}

Judging from the division of types of media by the experts above, song lyrics into print technology media groups. Seels and Glasglow group song lyrics into unprojected visual media groups that are included in traditional media choices [1]. Based on the above theory, it can be concluded that writing by giving suggestions through song lyrics aims to stimulate the imagination of students. Media song lyrics are used as creators of an atmosphere of suggestion, stimulus, and at the same time become a bridge for students to imagine or create images and events based on the theme of the song's lyrics. The expected response arises from the students in the form of the ability to see pictures of the event with their imaginations and logic, then express it again in the form of narrative writing.

The use of media "song lyrics" was chosen as a problem solving strategy on the basis of the consideration that in reality the world of children in their early teens is play and entertainment. Playing like that of children and even adults is very well liked and also entertainment. With the entertainment will be able to foster student creativity and also as a medium to explore desires and ideals that are desirable. Play and entertainment can be used to transfer knowledge, generate enthusiasm and motivation.

In learning in high schools that teachers face are transition students. At that time they were more inclined to entertainment, as was the case with film screenings, listening to music and songs. This will foster a high interest for students to learn.

\section{Conclusion}

Based on the analysis of conceptual ability to write a paragraph of narrative students through the medium of song lyrics can be deduced as follows: First, $m$ hrough serving popular songs of today and the lyrics of the song, the students' motivation to participate in the learning process be further improved so that students are more active and participative in every the stages of activities carried out. Secondly, hiburan be aired popular songs can make the atmosphere more enjoyable learning environment, fresh, alive, happy and relaxed but still have a conducive learning atmosphere. Third, $\mathrm{m}$ hrough media application lyrics, emotional state of students initially felt tired, not excited, seeing Indonesian lessons it difficult to be more entertained and fun and more quiet. Fourth, dith dikondisikannya students into discussion groups, all students mingle and work together well. Fifth, this learning media should be used by other teachers as an alternative in improving the quality of learning.

\section{Acknowledgements}

The author would like to thank the Sungai Aur State High School 1 for giving permission to carry out research and to the supervisor who has guided until the completion of this article.

\section{References}

[1] Arsyad, A.: Learning media. (Jakarta: Rajawali Press). (2009)

[2] Atmazaki.: Writing and editing tips. (Padang: UNP Press). (2007)

[3] Budianta, M, et al.: Reading Literature: Introduction to Understanding Literature for Higher Purpose. (Magelang: Indonesia Tera). (2003) 
[4] Eko W, Nugraheni.: The relationship between vocabulary mastery and student motivation with narrative text writing skills in grade xi students of smkn 1 sawit boyolali in the 2014/2015 academic year. Vol. 13, pp. 1-16. BASASTRA: Indonesian Literature Education Journal and Teaching. (2015)

[5] Keraf, G.: Arguments and narratives. (Jakarta: Gramedia Puataka Utama). (2007)

[6] Muhardi, Hasanuddin, W.S.: Fiction procedures and analysis. (Padang: IKIP Padang Press). (1992)

[7] Mulyono, S.: The effect of cooperative integrated reading and compotition (circ) learning model and reading ability on narrative writing skills of grade vii students of smpn in ngawi regency. Vol. 1, pp. 41-423. BASASTRA: Indonesian Literature Education Journal and Teaching. (2014).

[8] Nurgiyantoro, B.: theory of fiction study. yogyakarta: gadjah mada university press. in vocational high school students. Vol. 3, pp. 1-18, BASASTRA: Indonesian Literature Education Journal and Teaching (2010).

[9] Saddhono, K.: The application of picture anf picture method to improve motivation and narrative text writing skills. (2015).

[10] Semi, M. A.: Effective writing. (Padang: UNP Press). (2009)

[11] Tarigan, H. G.: Writing as a language skill. (Bandung: Space). (2005) 